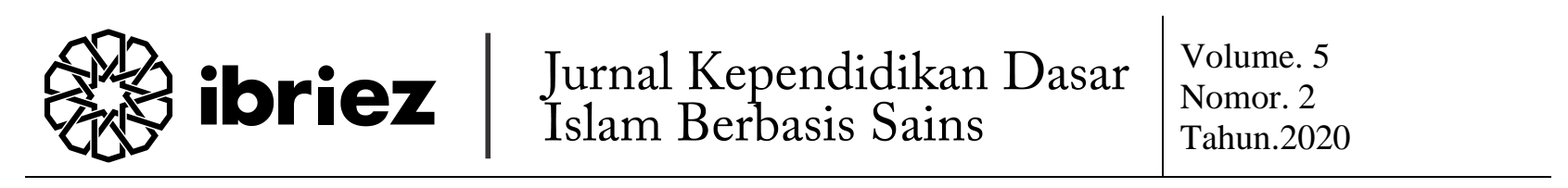

\title{
Model Pembelajaran Kooperatif tipe Student Teams Achievement Division (STAD) untuk Meningkatkan Prestasi Belajar
}

\author{
Siti Zulaikhah', Jusubaidi² \\ SMAN 1 Dagangan ${ }^{1}$ \\ IAIN Ponorogo ${ }^{2}$ \\ sitizulaikah368@gmail.com
}

\begin{abstract}
Abstrak
Metode pembelajaran yang kurang efektif dan efisien menyebabkan tidak seimbangnya kemampuan kognitif, afektif dan psikomotorik. Dengan menggunakan strategi pembelajaran yang sesuai, diharapkan dapat meningkatkan prestasi belajar peserta didik. Model pembelajaran yang bersifat kooperatif diharapkan dapat membantu dan mempermudah peserta didik dalam mempelajari konsep-konsep matematika dengan menyenangkan. Salah satu model pembelajaran yang bersifat kooperatif adalah model pembelajaran STAD. Penelitian ini bertujuan meningkatkan prestasi belajar matematika pada materi pertidaksamaan rasional dan irrasional untuk peserta didik kelas X MIPA dengan menggunakan model pembelajaran kooperatif tipe STAD. Pada metode ini diharapkan peserta didik yang berkemampuan tinggi membantu teman yang lain dalam satu kelompok sementara peserta didik yang berkemampuan rendah lebih terbuka dan tidak malu bertanya. Penelitian ini adalah penelitian tindakan kelas yang terdiri dari dua siklus. Tiap siklus dilaksanakan dalam 2 kali pertemuan, dimana masingmasing pertemuan berlangsung selama 90 menit. Konsep pokok penelitian tindakan kelas terdiri dari empat komponen, yaitu perencanaan, tindakan, observasi, dan refleksi. Penelitian ini dilaksanakan secara kolaboratif antara peneliti dengan teman sejawat sebagai observer. Hasil penelitian menunjukkan adanya peningkatan prestasi belajar peserta didik yang ditandai dengan peningkatan rata-rata hasil belajar dan peningkatan keaktifan peserta didik dalam mengikuti pembelajaran dari siklus I ke siklus II.
\end{abstract}

Kata kunci: Model Pembelajaran Kooperatif, STAD, Prestasi Belajar

\section{Abstract}

A less effective and less efficient method of learning leads to the imbalance of cognitive, affective and psychomotor skills. By using appropriate learning strategies, it is hoped that the students can 
improve their learning performances. Cooperative learning models are aimed to help and make it easier for learners to learn mathematical concepts in a fun way. One of the learning models in cooperative learning is the STAD model. This research aims to improve the learning performance of mathematics on the rational and irrational matter for students of class X MIPA by using STAD type Cooperative Learning Model. This method of learning involved higher-skilled learners to help their peers in the group who have difficulty learning the subject so they will be more open and not ashamed to ask more questions. This is a class action research consisting of two cycles. Each cycle is carried out in two meetings and each meeting lasting about 90 minutes. The basic concept of class action research made up of four components: planning, action, observation, and reflection. This research was conducted collaboratively between researchers and peers as well as an observer. The results showed an increase in student learning performance through an increase in the average learning outcomes and an increased activity of learners following the learning of the first cycle and second cycle.

Keywords: Cooperative Learning Model, STAD, learning achievement

\section{A. PENDAHULUAN}

Selama pembelajaran matematika, peserta didik senantiasa berhadapan dengan masalah yang harus dipecahkan secara sistematis. Peserta didik secara umum menganggap pelajaran matematika adalah pelajaran yang sulit. Hal ini disebabkan diantaranya karena peserta didik masih mempunyai kemampuan yang rendah dalam memahami konsep matematika. Selain itu, peserta didik juga tidak ada upaya atau malu menanyakan kesulitan yang dialami baik kepada guru atau teman sebaya saat memahami konsep maupun saat menyelesaikan soal matematika. Kemampuan peserta didik memahami konsep matematika yang rendah menyebabkan kesalahankesalahan dalam mengerjakan soal

\footnotetext{
${ }^{1}$ Partanto, Pius, M. Dahlan Al-Barry, "Kamus Ilmiah Populer"
}

sehingga mengakibatkan rendahnya prestasi belajar peserta didik.

Secara bahasa, prestasi belajar terbentuk dari dua kata, yaitu "prestasi" dan "belajar". Kata prestasi mengandung arti "hasil yang telah dicapai" sebagaimana dari kegiatan belajar. ${ }^{1}$ Prestasi belajar adalah penguasaan pengetahuan atau ketrampilan yang dikembangkan oleh mata pelajaran, lazimnya ditunjukkan dengan nilai tes yang diberikan oleh guru. ${ }^{2}$ Setiap peserta didik mempunyai prestasi yang berbeda.

Faktor-faktor yang mempengaruhi prestasi belajar peserta didik meliputi faktor eksternal dan faktor internal. Faktor eksternal yang dapat mempengaruhi prestasi belajar digolongkan dalam faktor sosial dan faktor

\footnotetext{
2 Tim Penyusun Kamus Pusat Pembinaan dan Pengembangan Bahasa Departemen Pendidikan dan Kebudayaan. "Kamus Besar Bahasa Indonesia”
} 
non-sosial. Sedangkan faktor internal mencakup faktor fisiologis dan faktor psikologis. $^{3}$ Menurut pendapat lain, faktor-faktor yang mempengaruhi belajar peserta didik dibedakan menjadi tiga macam, yaitu; faktor internal (keadaan jasmani dan rohani peserta didik), faktor eksternal (kondisi lingkungan disekitar peserta didik), dan faktor pendekatan belajar. ${ }^{4}$ Pada faktor pendekatan belajar diantaranya adalah pemilihan model pembelajaran yang tepat.

Model pembelajaran merupakan kerangka konseptual yang melukiskan prosedur yang sistematis dalam mengorganisasikan pengalaman belajar untuk mencapai tujuan belajar tertentu dan berfungsi sebagai pedoman bagi para perancang pembelajaran dan para pengajar dalam merencanakan aktifitas belajar mengajar. ${ }^{5}$ Model pembelajaran yang dapat digunakan untuk membangun keaktifan peserta didik dalam belajar diantaranya adalah model pembelajaran kooperatif.

Pembelajaran kooperatif mengacu pada metode pembelajaran dimana peserta didik bekerjasama dalam kelompok kecil dan saling membantu dalam belajar. Sistem pengajaran yang memberi kesempatan kepada anak didik untuk bekerjasama dengan sesama peserta didik dalam tugas-tugas yang terstruktur disebut sebagai pengajaran

\footnotetext{
${ }^{3}$ Mulyasa. "Psikologi Pendidikan"

${ }^{4}$ Muhibin Syah. "Psikologi Pendidikan dengan Pendekatan Baru"

5 Toeti Soekamto. "Teori Belajar dan Model-Model Pembelajaran"

${ }^{6}$ Iskandar S. "Pendekatan Pembelajaran SAINS

Berbasis Konstruktivisme"
}

gotong royong. ${ }^{6}$ Pada pembelajaran kooperatif diajarkan keterampilanketerampilan khusus agar dapat bekerjasama di dalam kelompoknya, seperti menjadi pendengar yang baik, memberikan penjelasan kepada teman sekelompok dengan baik, peserta didik diberi lembar kegiatan yang berisi pertanyaan atau tugas yang direncanakan untuk diajarkan. Selama kerja kalompok, tugas anggota kelompok adalah mencapai ketuntasan. ${ }^{7}$

Pembelajaran kooperatif yang paling sederhana adalah tipe Student Teams Achievement Division (STAD). STAD merupakan model pembelajaran kooperatif untuk pengelompokan peserta didik secara heterogen yang melibatkan pengakuan tim dan tanggung jawab kelompok untuk pembelajaran individu anggota. Tujuan dari pembelajaran ini adalah memberi pembelajaran kepada peserta didik untuk mampu berinteraksi dengan peserta didik lain dalam satu kelompok. ${ }^{8}$ Peserta didik dituntut bekerjasama dan saling membantu untuk mempelajari materi, menyelesaikan tugastugas bersama melalui kelompok yang beranggotakan 4-5 peserta didik yang berbeda dalam hal kemampuan, jenis kelamin, status sosial dan etnis atau budaya.

Model pembelajaran STAD merupakan sebagian dari pembelajaran

\footnotetext{
${ }^{7}$ Ibrahim, dkk. "Pembelajaran Kooperatif"

${ }^{8}$ Bambang Winarto. "Peningkatan Ketuntasan Hasil Belajar Matematika Menggunakan Model Cooperative Learning Tipe STAD melalui Pemanfaatan Alat Peraga"
} 
kooperatif yang dapat memacu peserta didik supaya dapat aktif bekerjasama serta memotivasi peserta didik supaya dapat saling mendukung dan membantu satu sama lain dalam menguasai kemampuan yang diajarkan oleh pendidik, model ini membantu mengaktifkan peserta didik dalam proses pembelajaran. ${ }^{9}$ Ada 6 fase yang harus dilakukan pada model pembelajaran tipe STAD, yaitu; (1) menyampaikan tujuan dan memotivasi peserta didik, (2) menyajikan informasi, (3) membentuk peserta didik dalam kelompok-kelompok belajar, membimbing kelompok bekerja dan belajar, (5) penilaian, (6) memberikan penghargaan.

Penggunaan model pembelajaran kooperatif tipe STAD diharapkan dapat membantu peserta didik dalam meningkatkan pemahaman terhadap materi pembelajaran, mempunyai semangat belajar, serta mengasah daya kreativitas. Berawal dari pemikiran tersebut peneliti melakukan penelitian tindakan kelas yaitu peningkatan prestasi belajar matematika menggunakan model pembelajaran kooperatif tipe STAD pada materi pertidaksamaan rasional dan irrasional.

\section{B. METODE PENELITIAN}

Penelitian ini merupakan penelitian tindakan kelas yang dilakukan secara langsung dalam kelas pada saat proses pembelajaran. Pengambilan data

\footnotetext{
${ }^{9}$ Heni D. M. "Efektivitas Model Pembelajaran
} Kooperatif Tipe Student Teams Achievement yang digunakan dalam penelitian ini menggunakan tes hasil belajar mengajar untuk mengetahui tingkat pemahaman peserta didik pada pembelajaran, observasi untuk melihat aktivitas belajar peserta didik, dan angket untuk mengetahui minat dan ketertarikan peserta didik pada pembelajaran. Adapun konsep pokok penelitian tindakan kelas terdiri dari empat komponen, yaitu perencanaan tindakan, pelaksanaan tindakan, observasi, dan refleksi. Berikut penjelasan keempat komponen tersebut.

\section{Perencanaan Tindakan}

Kegiatan yang dilakukan adalah menyiapkan perangkat pembelajaran yang meliputi: silabus materi pertidaksamaan rasional dan irrasional, menyusun rencana pelaksanaan pembelajaran (RPP) atau skenario pembelajaran model STAD, lembar kegiatan peserta didik, lembar observasi dan alat evaluasi.

\section{Pelaksanaan Tindakan}

Pada tahap ini merupakan pelaksanaaan rancangan skenario pembelajaran yang telah dibuat. Dimulai dengan penjelasan pada peserta didik tentang kegiatan yang harus dilakukan sebagaimana tergambar pada rencana pelaksanaan pembelajaran (RPP).

\section{Observasi / Pengamatan}

Observasi dilakukan pada waktu tindakan sedang berjalan. Pemantauan dilakukan untuk mengumpulkan data yang akan diolah untuk menentukan Sebaya Ditinjau Dari Kecerdasan Majemuk Siswa" 
tindakan yang akan dilakukan selanjutnya. Hal yang diamati yaitu keaktifan peserta didik dalam belajar, suasana pembelajaran, dan hasil belajar peserta didik.

\section{Refleksi}

Peneliti mengkaji, melihat dan mempertimbangkan hasil atau dampak dari tindakan yang dilakukan berdasarkan observasi saat kegiatan belajar mengajar dan dari hasil tes. Dari hasil refleksi ini, jika tujuan penelitian belum tercapai maka dilakukan tindakan perbaikan pada siklus berikutnya. Sebaliknya, jika tujuan penelitian sudah tercapai maka penelitian dihentikan.

Prosedur penelitian tindakan kelas yang dilaksanakan dalam 2 siklus dapat digambarkan pada bagan berikut.

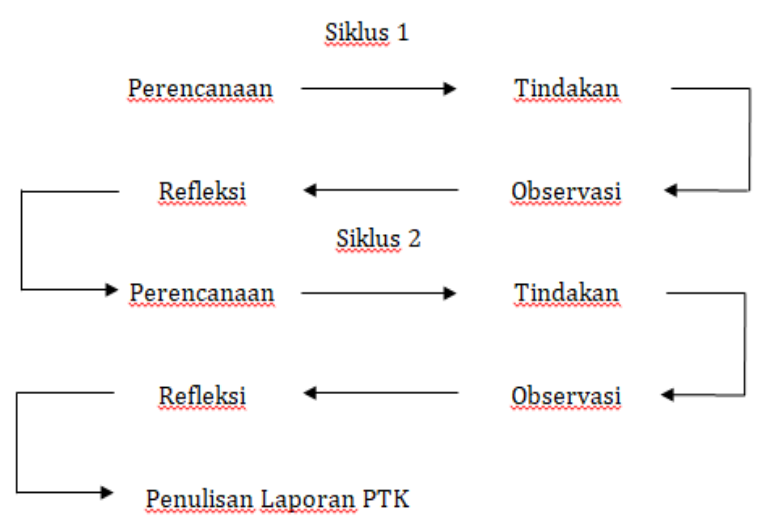

\section{Gambar 1 Tahapan Prosedur Penelitian Tidakan Kelas}

Dari gambar diatas dapat dilihat bahwa penelitian ini berlangsung menggunakan dua siklus karena pada siklus pertama belum mencapai hasil yang diinginkan. Setiap siklus melalui empat tahapan, yaitu (1) perencanaan, (2) tindakan, (3) observasi, dan (4) refleksi. Materi pada siklus II merupakan materi lanjutan dari materi pada siklus I. Materi siklus I adalah pertidaksamaan rasional dan materi pada siklus II adalah pertidaksamaan irrasional.

\section{HASIL DAN PEMBAHASAN}

Penelitian tindakan kelas ini terdiri dari dua siklus yaitu Siklus I dan Siklus II dengan menerapkan metode pembelajaran kooperatif tipe STAD. Pengukuran peningkatan prestasi belajar peserta didik melalui tes yang dilakukan tiap akhir siklus dalam bentuk soal uraian.

\section{Siklus I}

\section{a. Perencanaan Tindakan Siklus I}

Pada tahap ini kegiatan yang dilakukan adalah membuat silabus, menyusun rencana pelaksanaan pembelajaran (RPP) atau skenario pembelajaran model STAD untuk pembelajaran yang berlangsung selama 2 kali pertemuan dengan materi pertidaksamaan rasional dan lembar kegiatan peserta didik (LKPD) yang menekankan pada aktivitas mengamati, menganalisis, menyimpulkan dan membicarakan dengan teman sebaya. Selain itu juga membuat lembar observasi untuk memantau kegiatan pembelajaran dan membuat alat evaluasi untuk mengetahui keberhasilan belajar peserta didik.

\section{b. Pelaksanaan Tindakan Siklus I}

Pelaksanaan pembelajaran pada siklus I berlangsung selama dua kali pertemuan. Masing-masing pertemuan berlangsung selama $2 \times 45$ menit. Pada pelaksanaan tindakan ini guru melakukan kegiatan sesuai dengan apa yang telah direncanakan, dimulai dengan penjelasan 
mengenai metode STAD yang meliputi mendengarkan penjelasan materi yang disampaikan guru, diskusi kelompok membahas soal di lembar kegiatan peserta didik dan presentasi. Dengan adanya penjelasan itu, siswa akan mendapatkan gambaran yang jelas mengenai metode STAD sehingga siswa dapat melaksanakan kegiatan dengan baik. Adapun pengambilan nilai hasil belajar dilakukan pada pertemuan kedua siklus I. Diakhir pembelajaran guru memberikan penghargaan pada kelompok yang berhasil.

\section{c. Observasi Siklus I}

Pada saat observasi berlangsung kegiatan guru adalah memantau pelaksanaan metode pembelajaran STAD dengan materi pertidaksamaan rasional. Hasil observasi siklus I diperoleh ada beberapa peserta didik yang antusias setelah lembar kerja di bagikan dan ada beberapa peserta didik yang bermainmain atau asyik mengerjakan pekerjaan yang lain. Pada saat guru menyampaikan materi pertidaksamaan rasional, peserta didik memperhatikan dengan antusias. Pada saat pelaksanaan pengerjaan lembar kerja tersebut ada beberapa peserta didik yang mengalami kesulitan dalam menyelesaikan soal bertanya pada anggota kelompoknya, dan ada beberapa peserta didik yang tidak mengerjakan.

Berdasarkan lembar observasi aktivitas belajar peserta didik, ada beberapa hal yang belum bisa dicapai secara maksimal yaitu; kerjasama dalam kelompok, melakukan aktifitas bertanya, menggali anggota kelompok yang belum memahami materi pelajaran, membantu anggota kelompok yang belum memahami materi pelajaran dan mempresentasikan hasil diskusi kelompok kepada seluruh anggota. Pada saat dilaksanakan diskusi, guru belum secara optimal melayani tiap kelompok sehingga masih terdapat beberapa anak yang memang tidak berani bertanya secara terbuka kepada temannya menjadi lebih banyak diam dan tidak menyelesaikan lembar kegiatan dengan baik. Hal ini mengakibatkan pemahaman terhadap materipun berkurang.

Berdasarkan post tes pada pertemuan kedua didapatkan hasil 18 peserta didik dari 29 peserta didik mendapat nilai di atas batas ketuntasan atau di atas nilai 70 dengan prosentase sebesar $62,07 \%$ dan nilai rata-rata kelas yang dicapai 67,62.

\section{d. Refleksi Siklus I}

Pada hasil observasi dapat dilihat meskipun beberapa peserta didik nilainya mengalami penurunan namun secara umum model pembelajaran kooperatif tipe STAD dapat meningkatkan pemahaman peserta didik terhadap materi pelajaran pada siklus I. Hal ini dapat dilihat dari perolehan nilai rata-rata peserta didik yang meningkat dari 54,52 menjadi 67,62. Walaupun demikian, nilai rata-rata peserta didik belum memenuhi target yaitu diatas 75,00. Berdasarkan hasil analisa tersebut maka penelitian ini perlu dilanjutkan pada siklus II dengan memperbaiki kesalahan atau kekurangan 
yang dilakukan pada siklus I sehingga tujuan penelitian tercapai.

\section{Siklus II}

\section{a. Perencanaan Tindakan Siklus II}

Pada tahap ini kegiatan yang dilakukan adalah menyusun rencana pelaksanaan pembelajaran (RPP) atau skenario pembelajaran model STAD untuk pembelajaran yang berlangsung selama 2 kali pertemuan dengan materi pertidaksamaan irrasional dan lembar kegiatan peserta didik (LKPD) yang menekankan pada aktivitas mengamati, menganalisis, menyimpulkan dan membicarakan dengan teman sebaya. Selain itu juga membuat lembar observasi untuk memantau kegiatan pembelajaran dan membuat alat evaluasi untuk mengetahui keberhasilan belajar peserta didik.

\section{b. Pelaksanaan Tindakan Siklus II}

Pelaksanaan pembelajaran pada siklus II berlangsung selama dua kali pertemuan. Masing-masing pertemuan berlangsung selama 2 x 45 menit. Pada pelaksanaan tindakan ini guru lebih memotivasi pada peserta didik untuk membangun kebersamaan agar keberhasilan setiap anggota kelompok tercapai dan guru mendorong pada peserta didik yang mempunyai kemampuan lebih tinggi dalam kelompoknya untuk membantu peserta didik yang kemampuannya lebih rendah serta menganjurkan pada peserta didik yang mempunyai kemampuan lebih rendah untuk lebih terbuka dan tidak malu bertanya dan memberikan lembar kerja peserta didik untuk didiskusikan bersama di dalam kelompok. Hal ini dilakukan agar peserta didik dapat melaksanakan kegiatan dengan baik. Adapun pengambilan nilai hasil belajar dilakukan pada pertemuan kedua siklus II. Diakhir pembelajaran guru memberikan penghargaan pada kelompok yang berhasil.

\section{c. Observasi Siklus II}

Pada saat observasi berlangsung kegiatan guru adalah memantau pelaksanaan metode pembelajaran STAD dengan materi pertidaksamaan irrasional. Hasil observasi siklus II diperoleh peningkatan antusias peserta didik setelah lembar kerja di bagikan. Pada saat guru menyampaikan materi pertidaksamaan irrasional, peserta didik memperhatikan dengan antusias. Pada saat pelaksanaan pengerjaan lembar kerja tersebut peserta didik yang mengalami kesulitan dalam menyelesaikan soal bertanya pada anggota kelompoknya dan anggota yang lain menjelaskan penyelesaiannya.

Berdasarkan lembar observasi aktivitas belajar peserta didik, kerjasama kelompok berjalan dengan maksimal. Peserta didik berani bertanya pada temannya dalam satu kelompok dan anggota yang lain menjelaskan penyelesaiannya sehingga setiap peserta didik dalam satu kelompok mampu memahami materi pelajaran.

Berdasarkan post tes pada pertemuan kedua didapatkan hasil 26 peserta didik dari 29 peserta didik mendapat nilai di atas batas ketuntasan atau di atas nilai 70 dengan prosentase sebesar $89,66 \%$ dan nilai rata-rata kelas yang dicapai 82,21.

\section{d. Refleksi Siklus II}


Pada hasil observasi dapat dilihat tidak ada nilai peserta didik yang mengalami penurunan. Namun ada beberapa anak yang masih mendapat nilai dibawah ketuntasan. Hal ini dikarenakan kekurangtelitian peserta didik saat mengerjakan soal tes. Dengan demikian dapat disimpulkan model pembelajaran kooperatif tipe STAD dapat meningkatkan pemahaman peserta didik terhadap materi pelajaran pada siklus II. Hal ini dapat dilihat dari perolehan nilai rata-rata peserta didik yang meningkat dari 67,62 menjadi 82,21.

\section{Perbandingan Hasil Tindakan Antar Siklus dan Pembahasan}

Berdasarkan hasil penelitian tindakan pada siklus I dan II dapat dinyatakan bahwa terjadi peningkatan prestasi belajar pada materi pertidaksamaan rasional dan irrasional melalui penggunaan model pembelajaran kooperatif tipe STAD. Hal ini dapat diketahui dari peningkatan nilai pada tiaptiap siklus.

1. Siklus I

Pada siklus I membahas materi pertidaksamaan rasional. Berdasarkan hasil yang didapat dari instrument siklus I, nilai rata-rata kelas yang dicapai 67,62 . Peserta didik yang mendapat nilai lebih dari atau sama dengan 70 sebanyak 18 peserta didik dengan prosentase ketuntasan $62,07 \%$. Dari data itu terlihat nilai rata-rata yang dicapai peserta didik masih kurang dari target yaitu nilai rata- rata diatas 75,00, sehingga perlu dilakukan siklus selanjutnya.

2. Siklus II

Siklus II merupakan tindakan atas dasar kekurangan pada siklus I. materi pada siklus II adalah pertidaksamaan irrasional. Rata-rata hasil tes siklus II mencapai 82,21. Peserta didik yang mendapat nilai lebih dari atau sama dengan 70 sebanyak 26 peserta didik dengan prosentase ketuntasan 89,66\%. Nilai rata-rata yang dicapai peserta didik sudah melebihi target yaitu diatas nilai rata-rata 75,00 . Perbandingan nilai ratarata hasil tes dan prosentase ketuntasan dapat dilihat pada tabel 1.

Tabel 1 Perbandingan rata-rata hasil tes dan prosentase ketuntasan

\begin{tabular}{|l|c|c|c|}
\hline \multicolumn{1}{|c|}{ Kegiatan } & $\begin{array}{c}\text { Nilai } \\
\text { Dasar }\end{array}$ & Siklus I & Siklus II \\
\hline $\begin{array}{l}\text { Nilai Rata-rata hasil } \\
\text { belajar }\end{array}$ & 54,52 & 67,62 & 82,21 \\
\hline Prosentase Ketuntasan & $34,48 \%$ & $62,07 \%$ & $89,66 \%$ \\
\hline
\end{tabular}

Dari tabel diatas dapat menunjukan ada perubahan yang signifikan. Nilai dasar, siklus I dan siklus II mengalami peningkatan nilai rata-rata hasil belajar dan prosentase ketuntasan. Untuk lebih mudah melihat perubahan peningkatan hasil belajar dibuat grafik sebagai berikut: 
Implementasi Program Operasional ... | 201

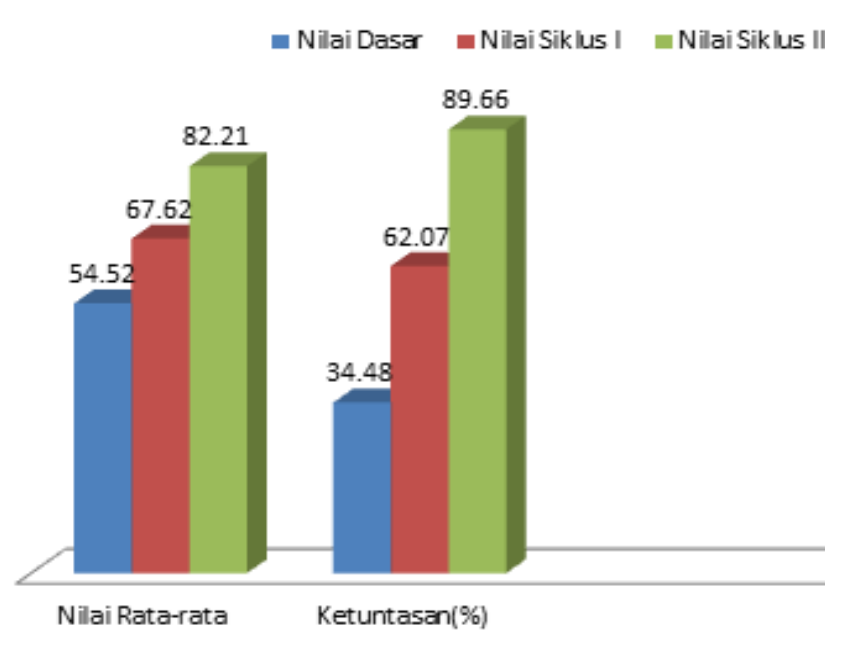

Gambar 2 Grafik Perbandingan Nilai ratarata dan prosentase ketuntasan

Dari hasil analisis diatas, dapat disimpulkan bahwa model pembelajaran kooperatif tipe STAD dapat meningkatkan prestasi belajar peserta didik pada materi pertidaksamaan rasional dan irrasional.

\section{PENUTUP}

Model pembelajaran STAD merupakan sebagian dari pembelajaran kooperatif yang dapat memacu peserta didik supaya dapat aktif bekerjasama serta memotivasi peserta didik untuk dapat saling mendukung dan membantu satu sama lain. Dalam kelompok harus membangun kebersamaan agar keberhasilan setiap anggota kelompok tercapai. Peserta didik yang mempunyai kemampuan lebih tinggi dalam kelompoknya harus membantu peserta didik yang kemampuannya lebih rendah. Sedangkan peserta didik yang mempunyai kemampuan lebih rendah untuk lebih terbuka dan tidak malu bertanya.

Dengan demikian, Model pembelajaran kooperatif tipe STAD telah dapat meningkatkan prestasi belajar Matematika peserta didik pada materi pertidaksamaan rasional dan irrasional.

\section{DAFTAR PUSTAKA}

Bambang Winarto. 2018. Peningkatan Ketuntasan Hasil Belajar Matematika Menggunakan Model Cooperative Learning Tipe STAD melalui Pemanfaatan Alat Peraga. Jurnal Pendidikan Matematika (Judika Education) Volume 1, No 1, JanuariJuni 2018

Heni D. M. 2014. Efektivitas Model Pembelajaran Kooperatif Tipe Student Teams Achievement Divisions (STAD) Yang Dimodifikasi Dengan Tutor Sebaya Ditinjau Dari

Kecerdasan Majemuk Siswa. Jurnal

Edutama, 1(1), 1-7.

Ibrahim, dkk. 2000. Pembelajaran

Kooperatif. Surabaya : UNESA

University Press.

Iskandar S. 2011. Pendekatan

Pembelajaran SAINS Berbasis

Konstruktivisme. BRILIANT: Jurnal

Riset dan Konseptual Volume 1

Nomor 1, November 2016 Malang:

Bayumedia Publising.

Muhibin Syah. 2001. Psikologi Pendidikan dengan Pendekatan Baru. Bandung : Remaja Rosdakarya.

Mulyasa. 2005. Psikologi Pendidikan.

Bandung : Remaja Rosdakarya.

Partanto, Pius, M. Dahlan Al-Barry. 1994.

Kamus Ilmiah Populer. Surabaya:

Apollo.

Tim Penyusun Kamus Pusat Pembinaan dan Pengembangan Bahasa 


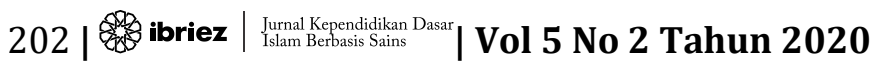

Departemen Pendidikan dan

Kebudayaan. Kamus Besar Bahasa

Indonesia. 1999. Jakarta: Balai

Pustaka.

Toeti Soekamto. 1997. Teori Belajar dan

Model-Model Pembelajaran. Jakarta:

PAV-PPAI UT 